\title{
AKTIVITAS ANTIOKSIDAN EKSTRAK RUMPUT LAUT Chaetomorpha antennina ASAL PESISIR UJONG SERANGGA ACEH BARAT DAYA
}

\section{THE ANTIOXIDANT ACTIVITY OF SEAWEED EXTRACT Chaetomorpha antennina FROM THE COAST OF UJONG SERANGGA SOUTHWEST ACEH}

\author{
${ }^{1}$ Mohamad Gazali, ${ }^{2}$ Muhammad Arif Nasution \\ ${ }^{1}$ Prodi Ilmu Kelautan, Fakultas Perikanan dan Ilmu Kelautan, Universitas Teuku Umar \\ Jalan Alue Peunyareng, Meulaboh, Aceh Barat 23615, Aceh ,Telepon (0655) 7003087 \\ ${ }^{2}$ Prodi Sumberdaya Akuatik Fakultas Perikanan dan Ilmu Kelautan, Universitas Teuku Umar \\ Jalan Alue Peunyareng, Meulaboh, Aceh Barat 23615, Aceh, Telepon (0655) 7003087
}

Korespondensi: mohamadgazali@utu.ac.id

\begin{abstract}
ABSTRAK
Rumput laut mengandung banyak senyawa bahan alam yang bersifat bioaktif. Beberapa senyawa di antaranya memiliki efek pharmaceutical. Tujuan penelitian ini adalah untuk mengkaji aktivitas antioksidan ekstrak rumput laut asal Pesisir Ujong Serangga Aceh Barat Daya. Manfaat penelitian ini diharapkan dapat menambah referensi tentang botani laut yang mempunyai aktivitas antioksidan dan alga hijau Chaetomorpha antennina dapat digunakan sebagai salah satu antioksidan alami bagi tubuh. Sampel Chaetomorpha antennina diambil dari pesisir Ujong Serangga Aceh Barat Daya. Selanjutnya, dimaserasi menggunakan 3 pelarut meliputi pelarut etanol (polar), etil asetat (semi polar) dan n-heksana (non polar). Hasil maserasi disaring dengan kertas saring Wathman nomor 42. Filtrat dievaporasi dengan rotary evaporator pada suhu $36^{\circ} \mathrm{C}$ dan tekanan rendah. Berdasarkan hasil penelitian menunjukkan bahwa dengan rataan berat sampel kering 30 gram diperoleh rataan rendemen sebesar $1,380 \%$ pada ekstrak etanol, 1,110\% pada ekstrak etil asetat dan 0,420\% pada ekstrak n-heksan. Nilai aktifitas antioksidan ekstrak etanol memiliki aktivitas antioksidan yang paling kuat dengan kapasitas antioksidan sebesar 91,05 $\mu$ mol Rutin Equivalence/g ekstrak, ekstrak etil asetat sebesar 16,77 $\mu$ mol Rutin Equivalence/g ekstrak dan ekstrak n-heksana sebesar $11.71 \mu \mathrm{mol}$ Rutin Equivalence/g ekstrak pada konsentrasi 0,1. Hasil ini mengindikasikan bahwa kapasistas antioksidan CUPRAC menunjukan bahwa ekstrak etanol memiliki aktivitas yang terbaik. Ekstrak etanol dari data di memiliki aktivitas antioksidan paling tinggi yang diduga mengandung asam hidroksinamat.
\end{abstract}

Kata kunci : Antioksidan, Chaetomorpha antennina, Senyawa Bioaktif

\begin{abstract}
Seaweed contain a lot of natural compound that attributed bioactive. Several compound possesess pharmaceutical effect. The aim of this research is to study antioxidant activity seaweed extracts from the coast of Ujong Serangga Soutwest Aceh. the benefits of this research was expected to add the references regarding marine botany that possesses antioxidant activity and green algae Chaetomorpha antennina can used as one of the natural antioxidant for human body. Chaetomorpha antennina sample was took from the coast of Ujong Serangga Soutwest Aceh. Subsequently, this sampe was macerated used 3 solvents includimg ethanol, ethyl acetate, and n-hexane. The result of maceration were filtered with Whatmant filter number 42. The filtrate were evaporated with rotary evaporatory with temperature $36{ }^{\circ} \mathrm{C}$ and slow pressure. According to the results showed the average dried sampel 30 gram were obtained average of rendement as much as $1,380 \%$ in ethanol extract, $1,110 \%$ in ethyl acetate acetatem and 0,420\% in n-hexane extract. Antioxidant activity value from ethanol extract possesses the strongest antioxidant activity with antioxidant capacity as much as 91,05 umol Equivalence/g extract, ethyl acetate as much as 16,77 $\mu$ mol Equivalence/g extract and n-hexane as much as 11,71 $\mu \mathrm{mol}$ Equivalence/g extract in 0,1 concentration. This indicate the capacity of antioxidant possesses the highest were suspected it contain hydrocinnamate acid.
\end{abstract}

Keywords : Antioxidant, Chaetomorpha antennina, Bioactive compound 


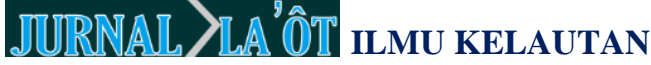

Volume I, Nomor 1, 2019
Available online at:

http://utu.ac.id/index.php/jurnal.html

\section{PENDAHULUAN}

Makroalga laut merupakan salah satu produsen primer di ekosistem perairan laut bersama dengan fitoplankton, lamun, dan mangrove. Sebagian jenis rumpu laut juga memiliki nilai ekonomis sebagai penghasil hidrokoloid (alginat, agar dan karagenan) yang secara luas digunakan dalam industri makanan dan farmaseutika. Jenis rumput laut ekonomis penting bahkan saat ini telah banyak dibudidayakan karena ketersediaan di alam tidak lagi mencukupi untuk berbagai kebutuhan manusia. Kementerian Kelautan dan Perikanan tahun 2015 melaporkan bahwa potensi luas areal budidaya rumput laut saat ini tercatat 1.1 juta hektar atau 9\% dari seluruh luas kawasan potensial budidaya laut yang sebesar 12 juta hektar.

Jenis rumput laut yang dimiliki Indonesia tercatat 555 jenis rumput laut dengan tingkat pemanfaatannya diperkirakan baru mencapai 25\%. Berdasarkan data Kementerian Perdagangan (2015) Indonesia menjadi pemasok utama rumput laut dunia dengan pangsa pasar sebesar $26.50 \%$ dari total permintaan dunia. Lima negara tujuan ekspor terbesar rumput laut adalah Tiongkok $(72.06 \%)$, Filipina $(5.82 \%)$, Chile $(4.89 \%)$, Korea (4.39\%) dan Vietnam (2.05\%). Rumput laut secara luas digunakan sebagai makanan, bahan penting bagi industri kosmetik serta penghasil hidrokoloid (alginat, agar dan karagenan) yang digunakan sebagai pengental dan gelling agents. Rumput laut juga digunakan untuk pengobatan berbagai penyakit. Potensi senyawa bioaktif berbagai jenis rumput laut telah dikaji dalam beberapa penelitian diantaranya adalah rumput laut hijau sebagai antioksidan (Novoa et al., 2011) dan antibakteri (Devi et al., 2009; Osman et al., 2013), rumput laut coklat sebagai antioksidan (Luo et al., 2010) dan antikanker (Anastyuk et al., 2012), serta rumput laut merah sebagai antiinflamasi (Vazquez et al., 2011). Menurut Perez et al., (2016) komponen bioaktif yang dihasilkan rumput laut diantaranya termasuk kelompok polisakarida, lemak dan asam lemak, pigmen, serta metabolit sekunder diantaranya fenol, alkaloid, terpen, dan lektin. Pereira dan Gama (2008) melaporkan lebih dari 300 metabolit sekunder telah diidentifikasi dari alga hijau, kurang dari setengahnya termasuk dalam Bangsa Bryopsidales. Suku Udoteaceae, Caulerpaceae dan Halimedaceae menghasilkan lebih dari 85\% komponen bioaktif dari ordo Bryopsidales yang telah dilaporkan.

Rumput laut merupakan jenis organisme yang cara hidupnya menetap di dasar perairan. Metabolit sekunder yang diproduksi biasanya untuk keperluan pertahanan diri dari gangguan predator alga seperti ikan, echinodermata, krustasea ataupun moluska. Maschek dan Baker (2008) melaporkan bahwa metabolit sekunder lebih sering ditemukan berkaitan antara interaksi organisme dengan lingkungan. Florotanin pada alga cokelat memberi kesan tidak menyenangkan terhadap predator sehingga melindungi dari serangan herbivora. Penelitian

Rumput laut diketahui banyak mengandung senyawa bahan alam yang bersifat bioaktif. Beberapa senyawa di antaranya memiliki efek "pharmaceutical" sekaligus berfungsi sebagai kosmetik, sehingga muncul istilah "cosmeceutical". Arti dari istilah tersebut menunjukkan karakter suatu produk yang berada pada kategori 
JURNAT \A (O)TI ILMU KELAUTAN

Volume I, Nomor 1, 2019

kosmetik dan obat (drugs) (AgatonovicKustrin et al., 2016). Ekstrak alga laut banyak digunakan untuk bahan perawatan kulit, karena dapat merangsang regenerasi kulit, mengurangi kerutan, mengurangi stres oksidatif dan meningkatkan sintesis kolagen (Fitton et al., 2016). Produk perawatan kulit "cosmeceutical" harus dapat memperbaiki fungsi dan struktur kulit, selain dapat meningkatkan penampakan kulit (Wang et al., 2015)

Radikal bebas merupakan senyawa kimia yang mempunyai satu atau lebih elektron tidak berpasangan yang dapat menyebabkan reaksi berantai (Badarinath et al., 2010). Reaksi berantai ini terjadi di dalam tubuh melalui proses metabolisme sel normal, peradangan dan adaya reaksi antara besi logam transisi dalam tubuh (Sayuti dan Yerina, 2015) serta terbentuk dari luar tubuh sebagai respons adanya sinar ultraviolet (UV), polusi lingkungan dan asap rokok (Wijaya, 1996). Radikal bebas didalam tubuh dapat menyebabkan pengerasan pembuluh jaringan, koroner, stroke, kanker, penyakit degeneratif seperti diabetes militus, inflamasi, arterosclerosis dan penuaan dini (Kang et al., 2010).

Radikal bebas adalah molekul yang reaktif, hal ini dikarenakan molekul tersebut memiliki satu atau lebih elektron dan untuk mengembalikan keseimbangannya, radikal bebas akan berusaha memperoleh electron dari molekul-molekul lain atau yang melepas electron yang tidak berpasangan (Waris dan Ahsan, 2006). Reactive Oxygen Species (ROS) merupakan hasil metabolisme aerobik
Available online at:

http://utu.ac.id/index.php/jurnal.html

normal dalam tubuh yang secara potensial dapat menyebabkan kerusakkan, secara luas diyakini terlibat sebagai penyebab berbagai penyakit seperti penuaan dini, kanker, penyakit jantung koroner, penyakit alzeimer, gangguan neurodegeneratif, aterosklerosis, katarak dan termasuk peradangan yang ditunjukkan dengan tanda-tanda stress oksidatif (Benzie dan Strain, 1996).

Senyawa ROS diantaranya adalah radikal anion superoksida, oksigen singlet, hidrogen peroksida dan radikal hidroksil yang sangat reaktif (Waris dan Ahsan, 2006). Penggunaan radikal bebas untuk analisis aktivitas antioksidan merupakan salah satu metode yang paling populer. Salah satu indikasi bahwa sampel uji berefek sebagai antioksidan adalah apabila sampel uji tersebut mempunyai kemampuan untuk menangkap radikal (Rohman et al., 2009). Salah satu radikal bebas yang digunakan adalah radikal DPPH (Gaikwad et al., 2010).

Pengujian antioksidan dilakukan juga dengan metode CUPRAC merupakan salah satu metode untuk melihat daya antioksidan senyawa-senyawa polifenol, dan Vitamin E yang dikenal mudah untuk dilakukan dan berbiaya rendah. Metode ini menggunakan reagen copper (II)neocuproine $(\mathrm{Cu}(\mathrm{II})-\mathrm{Nc})$. Metode ini dapat juga digunakan untuk mengetahui kapasitas antioksidan senyawa- senyawa fenolik (Apak et al., 2008).

Antioksidan adalah senyawa yang mampu menginaktivasi berkembangnya reaksi oksidasi dengan cara mencegah terbentuknya radikal bebas (Winarsi, 2007). Antioksidan secara endogen 


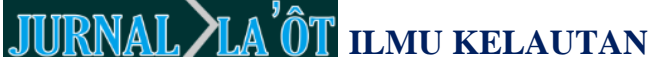

Volume I, Nomor 1, 2019

dihasilkan tubuh dan secara eksogen berasal dari makanan (Stahl dan Sies, 2003). Berdasarkan sumbernya antioksidan eksogen dibagi dua yaitu antioksidan sintetik dan alami. Antioksidan sintetik memiliki batas penggunaan $0,02 \%$ Tujuan penelitian ini adalah untuk mengkaji aktivitas antioksidan ekstrak rumput laut asal Pesisir Ujong Serangga Aceh Barat Daya. Manfaat penelitian ini diharapkan dapat menambah referensi tumbuhan yang mempunyai aktivitas antioksidan dan rumput laut Chaetomorpha antennina dapat digunakan sebagai salah satu antioksidan alami bagi tubuh.
\end{abstract}

\section{METODE PENELITIAN \\ Waktu dan Tempat}

Pengambilan sampel dilaksanakan di Pesisir Ujong Serangga Kabupaten Aceh Barat Daya Propinsi Aceh (Gambar 1). Kemudian, sampel tersebut diuji di Laboratorium. Penelitian ini dilaksanakan pada bulan Maret hingga November 2018 bertempat di Laboratorium Bahan Baku Hasil Perairan Departemen Teknologi Hasil Perairan, Fakultas Perikanan dan Ilmu Kelautan, Institut Pertanian Bogor

\section{Material}

Material yang digunakan meliputi batang pengaduk, cawan porselin, corong, eksikator, gelas arloji, gelas kimia (pyrex), gelas ukur (pyrex), kamera, pinset, pipet tetes, pipet skala, rak tabung, sendok tanduk, seperangkat alat rotavapor, seperangkat alat maserasi, spektrofotometer Ultraviolet Visibel, tabung reaksi, dan timbangan analitik, sedangkan bahan-bahan yang digunakan adalah aluminium foil, aquadest, buffer amonium
Available online at:

http://utu.ac.id/index.php/jurnal.html

asetat, $\quad \mathrm{CuCl}_{2}, \quad$ ekstrak Chaetomorpha antennina etanol 96\%, neokuproin dan tissue.

\section{Metode Penelitian}

Jenis Penelitian

Penelitian ini dilakukan secara eksperimental dengan menggunakan metode CUPRAC untuk membuktikan adanya aktivitas antioksidan rumput laut hijau Chaetomorpha antennina di Laboratorium.

\section{Cara Kerja}

a. Pengambilan dan Pengolahan Sampel Pengambilan sampel rumput laut hijau Chaetomorpha antennina di Pesisir Pesisir Ujong Serangga Aceh Barat Daya dengan cara mengambil talus yang masih segar secara manual menggunakan tangan. Sampel tersebut kemudian dikumpulkan, dicuci dengan air mengalir. Rumput laut hijau Chaetomorpha antennina kemudian dikeringkan di bawah sinar matahari dengan ditutup kain hitam. Sampel yang sudah kering kemudian diserbukkan menggunakan blender.

b. Pembuatan ekstrak

250 gr sampel Chaetomorpha antennina dimaserasi menggunakan etanol 96\%, etil asetat dan n-heksane. Ekstraksi senyawa bioaktif dilakukan menggunakan metode maserasi 


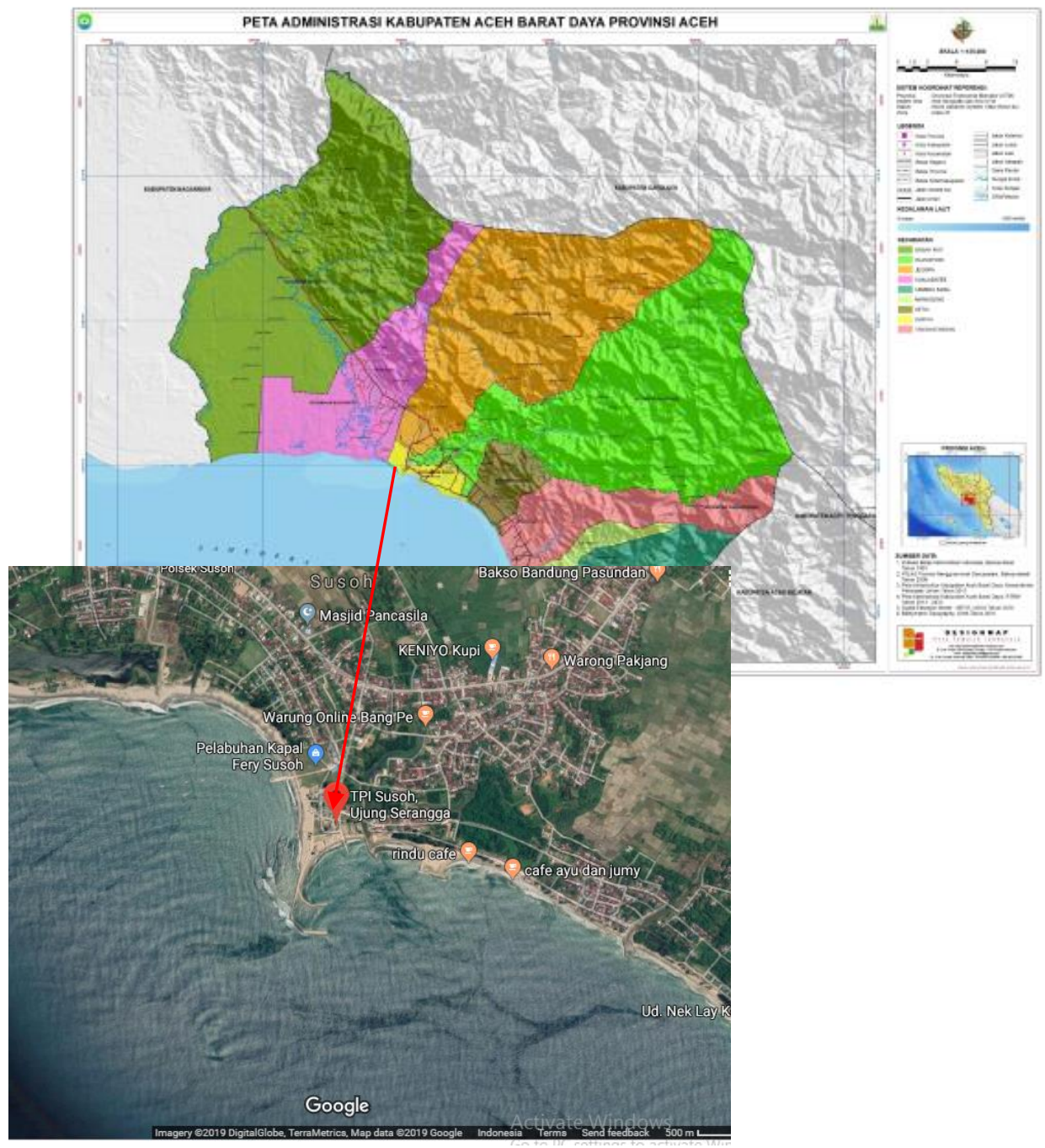

Gambar 1. Lokasi Sampling

Sumber : https://petatematikindo.files.wordpress.com/2013/04/

(ekstraksi tunggal) dengan metanol teknis selama 24 jam pada suhu ruang (3 x pengulangan maserasi). Hasil maserasi disaring dengan kertas saring Wathman nomor 42. Filtrat dievaporasi dengan rotary evaporator pada suhu $36^{\circ} \mathrm{C}$ dan tekanan rendah. Ekstrak yang diperoleh disimpan dalam vial pada suhu rendah $\left(4^{\circ} \mathrm{C}\right)$ sebelum digunakan untuk analisis.
Rendemen ekstrak dihitung menggunakan rumus:

$$
\text { Rendemen Ekstrak (\%) }=\frac{\text { Berat ekstrak }(\mathrm{g})}{\text { Berat sampel (g) }} \times 100 \%
$$

c. Penyiapan Larutan (Apak et al., 2007).

Larutan $\mathrm{CuCl}_{2}$ 1,0X10-2 $\mathrm{M}$ dibuat dengan melarutkan 0,4262 gram $\mathrm{CuCl}_{2} .2 \mathrm{H}_{2} \mathrm{O}$ dalam air dan diencerkan sampai $250 \mathrm{~mL}$. Buffer ammonium asetat pada $\mathrm{pH} 7$ disiapkan dengan 


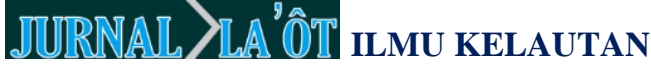

Volume I, Nomor 1, 2019

melarutkan 19,27 gram $\mathrm{NH}_{4} \mathrm{Ac}$ dalam air dan diencerkan sampai $250 \mathrm{~mL}$. Larutan Neocuproine (Nc) 7,5X10-3 $\mathrm{M}$, disiapkan dengan melarutkan 0,039 gram Nc dalam etanol $96 \%$ dan diencerkan sampai $25 \mathrm{~mL}$ dengan etanol $96 \%$.

d. Uji Aktivitas Antioksidan dengan

Metode CUPRAC (Widyastuti, et al., 2010).

Uji CUPRAC telah dikerjakan dengan cara $1 \mathrm{~mL}$ ekstrak atau fraksi dalam etanol 96\%, $1 \mathrm{~mL} \mathrm{CuCl} 2.2 \mathrm{H}_{2} \mathrm{O} 0,01 \mathrm{M}$; $1 \mathrm{~mL}$ neokuproin etanolik $0,0075 \mathrm{M} ; 1$ mL buffer $\mathrm{NH}_{4} \mathrm{Ac}$ pH $7 \quad 1 \mathrm{M}$; dan sejumlah akuades hingga volumetrik (nilai faktor pengenceran). Larutan didiamkan selama 30 menit dan diukur absorbansinya pada panjang gelombang 453,4 nm. Blanko digunakan dengan mengukur absorbansi semua larutan tanpa ekstrak. Kurva baku dibuat dengan larutan troloks dengan rentang seri konsentrasi 18,75-200 ppm. Kapasitas antioksidannya dinyatakan dalam $\mu$ mol troloks/g sampel. Artikel ini difokuskan pada hasil uji antioksidan.

\section{HASIL DAN PEMBAHASAN \\ Deskripsi Rumput Laut Chaetomorpha antennina}

Kebanyakan rumput laut liar yang ditemukan terdapat pada subtrat karang. Hal ini disebabkan karana rumput laut yang menancap di karang lebih kuat bertahan ditrerjang ombak dan arus yang kuat. Subtrat yang baik untuk budidaya rumput laut adalah pasir dan patahan karang (Hambali et al., 2012). Pantai yang berpasir biasanya tidak banyak ditumbuhi oleh tumbuhan laut seperti
Available online at:

http://utu.ac.id/index.php/jurnal.html

rumput laut dan lamun karena gerakan air laut dan gelombang akan menyebabkan pergerakan subtrat sehingga tidak terdapat tempat yang cocok bagi tumbuhan laut untuk melekat (Nybakken, 1992). Habitat Chaetomorpha antennina yaitu pada daerah pasang surut laut yang berdasar karang pasir. Melekat pada pecahan karang atau substrat padat lainnya. Pada musim tertentu biasanya tumbuh sangat banyak bersama kelompok Chaetomorpha dan Ulva (Sulisetjono, 2009).

Chaetomorpha antennina yang tersebar di pesisir pantai Ujong Serangga Aceh Barat Daya kebanyakan menempel pada substrat berbatu dengan ombak yang kuat sehingga spesies tersebut menempel dengan kuat pada substrat batu. Pesisir Ujong Serangga terdapat TPI Ujong Serangga sebagai tempat pelelangan ikan hasil tangkapan. Chaetomorpha antennina yang ditemukan pada batuan penghalang ombak yang dibuat secara buatan yang bertujuan sebagai penangkal ombak.

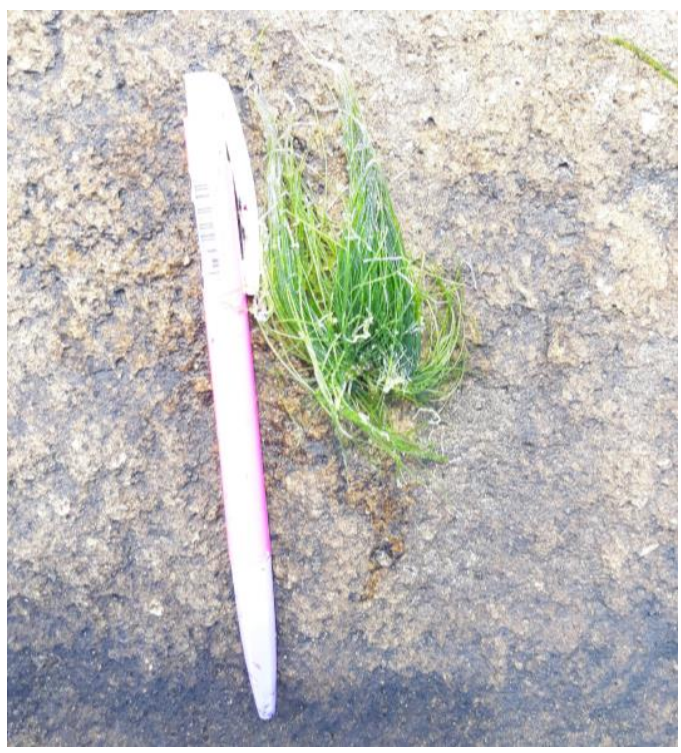

Gambar 2. Spesies Chaetomorpha antennina pada Substrat Batuan di Pesisir Ujong Serangga Aceh Barat Daya. 


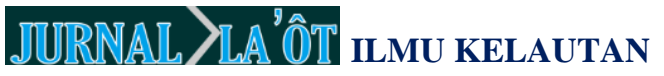

Volume I, Nomor 1, 2019

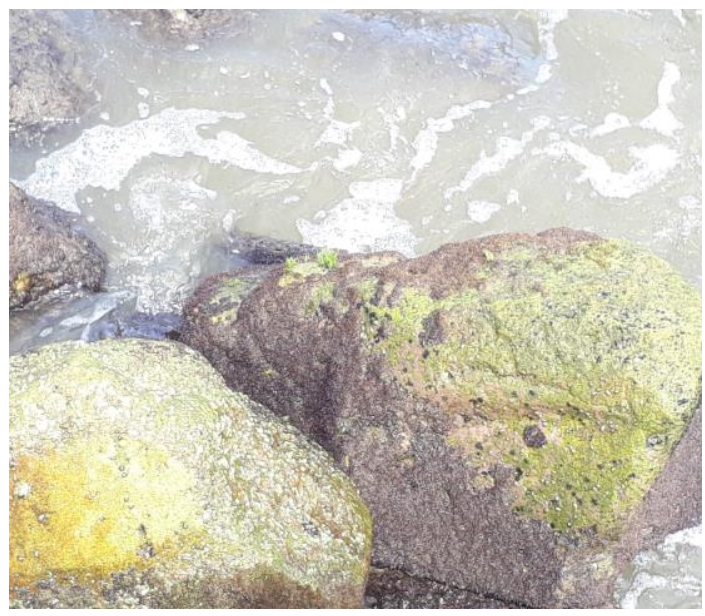

Gambar 3. Habitat Spesies Chaetomorpha antennina pada Substrat Batuan

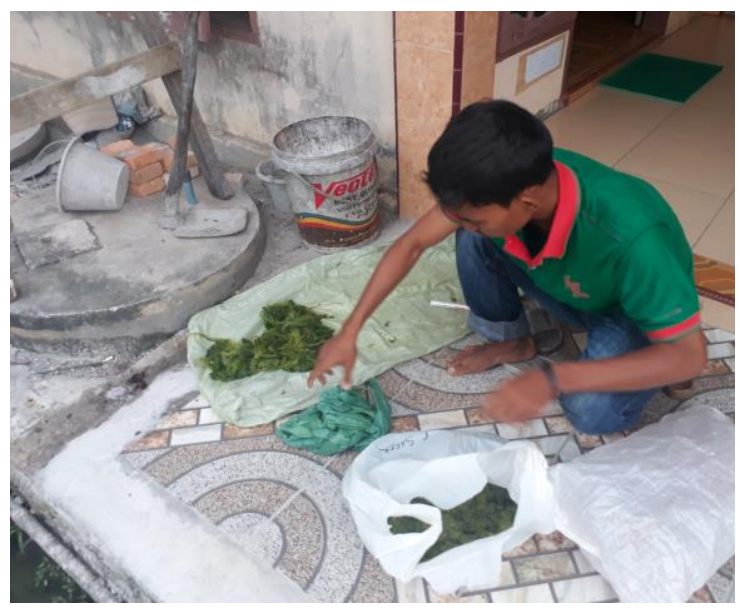

Gambar 4. Spesies Chaetomorpha antennina yang dikeringkan dibawah sinar matahari

\section{Rendemen}

Rendemen merupakan persentase bagian bahan baku yang dapat digunakan atau dimanfaatkan dengan total bahan baku. Menurut Kusumawati et al., (2008) Semakin tinggi nilai rendemen menandakan bahwa bahan baku tersebut memiliki peluang untuk dimanfaatkan lebih besar. Rendemen merupakan persentase sampel sebelum dan setelah perlakuan.
Available online at:

http://utu.ac.id/index.php/jurnal.html

Rendemen Chaetomorpha antennina adalah efektifitas massa produk setelah proses pengeringan dan sebelum proses pengeringan. Tabel 1. Rendemen

\begin{tabular}{lc}
\hline Ekstrak & Rendemen $(\%)$ \\
\hline Etanol & 1,380 \\
Etil Asetat & 1,110 \\
N-Heksan & 0,420 \\
\hline
\end{tabular}

Hasil yang diperoleh menunjukan bahwa dengan rataan berat sampel kering 30 gram diperoleh rataan rendemen sebesar 1,380\% pada ekstrak etanol, $1,110 \%$ pada ekstrak etil asetat dan 0,420\% pada ekstrak n-heksan. Ekstrak ini berbentuk pasta berwarna coklat pekat. Hal ini menunjukkan bahwa Hasil rendemen ini menunjukkan bahwa kadar rendemen ekstrak etanol lebih tinggi daripada ekstrak air sebab etanol dapat melarutkan senyawa polar dan nonpolar.

\section{Aktivitas Antioksidan}

Pengujian antioksidan dilakukan dengan dua metode yaitu CUPRAC. Pada metode CUPRAC (cupric ion reducing antioxidant capacity), kompleks bisneokuproin-tembaga(II)akan mengoksidasi senyawaan antioksidan dalam ekstrak tanaman dan mengalami reduksi membentuk kompleks bis-neokuproin-tembaga(I). Secara visual hal ini dapat dilihat dari perubahan warna kompleks larutan dari biru toska menjadi kuning. Pereaksi CUPRAC merupakan pereaksi yang selektif karena memiliki nilai potensial reduksi yang rendah, yaitu sebesar 0,17 V (Apak et al., 2007). Hasil pengukuran kapasitas antioksidan dengan metode CUPRAC ditunjukkan pada Tabel 1. 
JURNAT \A (O)T ILMU KELAUTAN

Volume I, Nomor 1, 2019

Tabel 1. Kapasitas Antioksidan Metode CUPRAC

\begin{tabular}{lc}
\hline Ekstrak & $\begin{array}{c}\text { Kapasitas Antioksidan } \\
(\mu \mathrm{mol} \text { troloks/g serbuk } \\
\text { kering })\end{array}$ \\
\hline Etanol & 91.05 \\
Etil asetat & 16.77 \\
n-heksana & 11.71 \\
\hline
\end{tabular}

dengan metode CUPRAC juga memperlihatkan adanya aktifitas antioksidan yang positif. Nilai aktifitas antioksidan ekstrak etanol memiliki aktivitas antioksidan yang paling kuat dengan kapasitas antioksidan sebesar 91,05 $\mu \mathrm{mol}$ Rutin Equivalence/g ekstrak, ekstrak etil asetat sebesar 16,77 $\mu \mathrm{mol}$ Rutin Equivalence/g ekstrak dan ekstrak n-heksana sebesar 11.71 pada konsentrasi 0,1 (Tabel 1). Metode CUPRAC sendiri digunakan lebih banyak pada pengujian kapasitas antioksidan untuk senyawasenyawa fenolik (Apak, 2008). Oleh karena itu, dari ekstrak kasar tersebut diprediksi memilki kandungan senyawa-senyawa fenolik yang cukup banyak. Hasil pengujian kapasistas antioksidan CUPRAC menunjukan bahwa ekstrak etanol memiliki aktivitas yang terbaik. Ekstrak etanol dari data di atas memiliki aktivitas antioksidan paling tinggi yang diduga mengandung asam hidroksinamat (Alabi et al., 2005). Asam hidrosinamat termasuk golongan polifenol dan dapat berperan sebagai zat antioksidan karena memiliki atom hidrogen dari gugus hidroksil yang dapat disumbangkan pada radikal bebas. Identifikasi senyawa secara kuantitatif (total fenolik dan total flavonoid) juga dilakukan dengan kualitatif. Identifikasi
Available online at:

http://utu.ac.id/index.php/jurnal.html

dilakukan dengan deteksi flavonoid, polifenol, alkaloid dan terpenoid.

\section{KESIMPULAN DAN SARAN \\ Kesimpulan}

Berdasarkan hasil penelitian dapat disimpulkan bahwa ekstrak Chaetomorpha antennina yang berasal di pesisir Ujong Serangga Kabupaten Aceh Barat Daya mempunyai aktivitas antioksidan pada ekstrak etanol. Hasil ini mengindikasikan bahwa kapasistas antioksidan CUPRAC menunjukan bahwa ekstrak etanol memiliki aktivitas yang terbaik. Ekstrak etanol dari data di memiliki aktivitas antioksidan paling tinggi yang diduga mengandung asam hidroksinamat.

\section{Saran}

Dengan diketahui bahwa yang tumbuh di Chaetomorpha antennina daerah Pesisir Ujong Serangga memiliki aktivitas antioksidan yang baik. maka penelti menyarankan untuk melakukan penelitan lebih lanjut memurnikan senyawa antioksidan tersebut yang diduga merupakan senyawa golongan fenolik. Sehingga dapat menghasilkan suatu produk antioksidan alami yang diharapkan dapat mengganti antioksidan sintetik

\section{UCAPAN TERIMA KASIH}

Ucapan terima kasih yang setinggitingginya kepada mahasiswa Prodi Sumberdaya akuatik FPIK Universitas Teuku Umar dan Laboratorium Departemen Teknologi Hasil Perairan FPIK Institut Pertanian Bogor yang membantu dalam melakukan pengujian laboratorium 


\section{DAFTAR PUSTAKA}

Alabi DA, Akinsulire OR, Sanyaolu MA. 2005. Qualitative determination of chemical and nutritional compotition of Parkia Biglobosa (Jacq) Benth. Afr J Biotechnol 4:812-815.

Anastyuk S, Shevchenko N, Ermakova S, Vishchuk O, Nazarenko E, Dmitrenok PS, Zvyaginseva TN. 2012. Anticancer activity in vitro of a fucoidan from the brown alga Fucus evanescens and its low-molecular fragments, structurally characterized by tandem massspectrometry. Carbohydrate Polymers (87):186-194.

Apak, R. Kubilay,G. Mustafa, O. And Saliha E.C., 2007. Mechanism of antioxidant capacity assays and the CUPRAC (cupric ion reducing antioxidant capacity) assay. Microchim Acta (2008) 160: 413-419. DOI 10.1007/s00604-007-0777-0.

Apak, R., Gu“c_lu, K., Ozyürek, M., dan Esin C_elik, S. 2008. Mechanism of antioxidant capacity assays and the CUPRAC (cupric ion reducing antioxidant capacity) assay. SpringerVerlag, 160. 413-419.

Badarinath, A.V., RAo, K.M., Chetty, C.M.S., and Ramkanth, S. 2010. A Review on In-Vitro Antioxidant Methods: Comparisons, Correlations and Considerations. International Journal of PharmTech Research, 2(2): 1276-1285 pp.
Available online at:

http://utu.ac.id/index.php/jurnal.html

Hambali, M., Jaya, Y.V. \& Irawan, H., 2012. Aplikasi SIG Untuk Kesesuaian Kawasan Budidaya Rumput Laut Eucheuma cottonii dengan Metode Lepas Dasar di Pulau Mantang, Kecamatan Mantang, Kabupaten Bintan. Maritime Raja Ali Haji University, pp.1-8.

Agatonovic-Kustrin, S, D. W. Morton, and P. Ristivojevic. 2016. Assessment of Antioxidant Activity in Victorian Marine Algal Extracts Using High Performance Thin-Layer Chromatography and Multivariate Analysis. Journal of Chromatography A., 1468: 228-35.

Benzie, I.F. dan Strain, J.J. (1996). The ferric reducing ability of plasma (FRAP) as a measure of "antioxidant power": the FRAP assay. Analytical biochemistry, 239,70-76.

Devi GK, Manivannan K, Thirumaran G, Anantharaman P, Balasubaramanian T. 2009. Antibacterial properties of selected green seaweeds from Vedalai coastal waters Gulf of Mannar: marine biosphere reserve. Global Journal of Pharmacology 3 (2):107-112.

Fitton, H. J, T. Oddie, D. Stringer, and S. K. Marinova. 2016. Marine Plant Extracts Offer Superior Dermal Protection OH. (March): 51-54.

Gaikwad, P. Barik, A. Priyadarsini, K.I. dan Rao, B.S.M. 2010. Antioxidant activities of phenols in different solvents using DPPH assay. Research on Chemical Intermediates, 36, 1065-1072. 
JURNAR \A (O)TI ILMU KELAUTAN

Volume I, Nomor 1, 2019

Kusumawati R., Tazwir., Wawanto A. 2008. Pengaruh Rendemen Dalam Asam Klorida Terhadap Kualitas Gelatin Tulang Kakap Merah (Lutjanus sp.). Jurnal Pascapanen dan Bioteknologi Kelautan Dan Perikanan. 3(1): 63-68.

Kang, C., Jin, B., Lee, H., Cha, M., Sohn. E., Moon, J., Park, C., Chun, S., Jung, E., Hong, J.S., Kim, J., and Kim, E. 2010. Brown algae Eclonia cava attenuates type 1 diabetes by activating AMPK and AKT signaling pathways. Journal of Food Chemistry and Toxicology, 48: 509-516 pp.

[KKP]. Kementerian Kelautan dan Perikanan. 2015. Laporan kinerja KKP tahun 2015. [diunduh 2019 Maret 23]. Tersedia pada: http://www.kkp.go.id.

Luo HY, Wang B, Yu CG, Qu YL, Su CL. 2010. Evaluation of antioxidant activities of five selected brown seaweed from China. Journal of Medical Plant Research 4 (18):2557-2565. doi: 10.5897/JMPR10.609.

Mishra JK, Srinivas T, Madhusudan T, Sawhney S. 2016. Antibacterial activity of seaweed Halimeda opuntia from the coasts of South Andaman. Global Journal of Bioscience and Biotechnology 5(3):345-348.

Maschek JA, Baker BJ. 2008. The chemistry of algal secondary metabolism. Di dalam: Amsler CD, editor. Algal Chemical Ecology. Birmingham (US):

Springer. hlm 1-25.
Available online at:

http://utu.ac.id/index.php/jurnal.html

Novoa AV, Wartha ER, Linares AF, Silva M, Genovese MI, Gonzalez AE, Costa A, Filho JM. 2011. Antioxidant activity and possible bioactive components in hydrophilic and lipophilic fractions from the seaweed Halimeda incrassate. Brazilian Journal of

Pharmacognosy $21 \quad$ (1):53-57. doi:10.1590/S0102$695 \times 2011005000010$.

Nybakken, 1992. Bologi Laut. In suatu pendekatan ekologis. Jakarta: Gramedia.

Osman MEH, Aboshady AM, Elshobary ME. 2013. Production and characterization of antimicrobial active substance from some macroalgae collected from AbuQir Bay Alexandria Egypt. African Journal of Biotechnology 12 (49): 6847-6858.

DOI: 10.5897/AJB10.2150.

Perez MJ, Falqué E, Domínguez H. 2016. Antimicrobial action of compounds from marine seaweed-a review. Marine Drugs 14 (52):1-38.

Rohman, A. Riyanto, S. Dahliyanti, R. dan Pratomo, D. 2009. Penangkapan radikal

2,2-Difenil-1-Pikril Hidrazil oleh ekstrak buah Psidium guajava.L dan Averrhoa carambola L. Jurnal Ilmu Kefarmasian Indonesia., 7(1). 1-5.

Sayuti, K., dan Yenrina, R. 2015. Antioksidan Alami dan Sintetik. Andalas University Press, Padang, $112 \mathrm{hlm}$.

Stahl, W., and Sies, H. 2003. Antioxidant Activity of Carotenoids. Molecular 


\section{JURNAR \AA (0)T ILMU KELAUTAN}

Volume I, Nomor 1, 2019

Asfects of Medicine, 24: 345-351

pp.

Vazquez A, Sanchez C, Delgado N, Alfonso A, Ortega Y, Sanchez H. 2011. Antiinflammatory and analgesic activities of red seaweed Dichotomaria obtusata. Brazilian Journal of Pharmaceutical Sciences (47):111-118.

Wang, H. M. D., C. C. Chen, P. Huynh, and J. S. Chang. 2015. Exploring the Potntial of Using Algae in Cosmetics. Bioresource Technology., 184:355362.

Waris, G. dan Ahsan, H. 2006. Reactive oxygen species: role in the development of cancer and various chronic conditions. Journal of carcinogenesis, 5 (14)

Widyastuti, N. 2010. Pengukuran aktivitas antioksidan dengan metode CUPRAC, DPPH, dan FRAP serta kolerasinya dengan fenol dan flavonoid pada enam tanaman. Institut Pertanian Bogor. Bogor.

Wijaya, A. 1996. Radikal Bebas dan Parameter Status Antioksidan. Forum Diagnosticum. Laboratorium Klinik Prodia, 1: 1$12 \mathrm{hlm}$.

Winarsi, H. 2007. Antioksidan Alami dan Radikal Bebas. Kanisius, Yogyakarta.
Available online at: http://utu.ac.id/index.php/jurnal.html 